\title{
COMPLEMENTARITIES BETWEEN INSTITUTIONS AND OpenNess in EConomic Development: Evidence FOR A PANEl OF COUNTRIES*
}

\author{
CÉSAR CALDERÓN \\ The World Bank \\ RODRIGO FUENTES \\ Central Bank of Chile
}

The main goal of the paper is to evaluate the sources of growth in Chile and the world in the last three decades, but stressing the role of complementarities in economic policies. Therefore, we evaluate the growth determinants for a sample of seventy-eight countries with information over the 1970-2000 period. In contrast to Gallego and Loayza (2002), we test directly the existence of complementarities between trade and financial liberalization policies with: a) the initial conditions of the economy, b) human capital policies, and c) the quality of institutions.

JEL: F36, F41, F43

Keywords: External Stocks, Openness, Volatility, Growth.

\section{INTRODUCTION}

The empirical literature on economic growth offers a wide variety of studies that analyze the effects of economic policies and institutions on economic growth. In the case of Chile, a large part of the sustained economic growth over the socalled golden period (1986-97) could be attributed to good policies and structural reforms implemented in the country. However, other countries have implemented similar policies and they have been unable to achieve analogous results. In this respect, Rodrik (2005) argues that there is not a unique mapping from economic

\footnotetext{
*We would like to thank Rodrigo Cifuentes, José De Gregorio, Klaus Schmidt-Hebbel and Rodrigo Valdés for helpful comments to an earlier version of this paper. The views expressed herein are those of the authors and are not necessarily shared by the institutions they represent.

E-mails: ccalderon@worldbank.org,rfuentes@bcentral.cl
} 
principles to policy packages. Successful countries have followed different strategies to implement reforms with a wide range of results.

We argue that the key element behind different development outcomes across countries lies in the notion of policy complementarities, which are crucial to determine whether a specific policy package help to enhance economic growth. The notion of policy complementarities is closely associated with the challenges of globalization in the world economy. In this respect, policy complementarities play an important role as economies develop closer links to each other through increasing trade and capital flows as well as technological transfers (Aziz and Wescott, 1997). Therefore policy complementarity has become a cornerstone to start up economic growth. Pro-growth policies are mutually reinforcing -for instance, financial openness will have positive and substantial growth effects in countries with solid institutions. However, policy complementarities can also impose severe restrictions in the design of the optimal growth strategy, especially among countries with unfavorable initial conditions or resistance to reform.

The goal of this paper is twofold. First, we assess the contribution of structural reforms and good policies to economic growth for Chile and compare a result to a large group of economies, using data for the last three decades. To accomplish this, we conduct a regression analysis for a sample of seventy-eight countries with data for the 1970-2000 period. Second, we proceed to test the conjecture that Chile's good performance relative to other economies is due to policy complementarities.

The issue of policy complementarities as a source of economic growth was first addressed by Gallego and Loayza (2002). They evaluate the role of economic policy complementarities on growth by including in their regression analysis a dummy variable that takes the value of one if all measures of a set of policy indicators have higher values than the corresponding world median, and zero otherwise. ${ }^{1}$ These authors find that policy complementarities are important not only for Chile but also for other high-performing countries like Ireland, Korea, the Netherlands, and Thailand. One of the shortcomings of this indicator is that, although it accounts of the presents of policy complementarities, it does not quantify their extent or intensity.

In contrast to Gallego and Loayza (2002) we will directly test policy complementarities using interaction among specific policy dimensions. We acknowledge that it is practically impossible to specify all the potential policy complementarities in a regression equation due to lack of degrees of freedom. Here we are specifically interested in testing the complementarities of both trade and financial openness with the quality of institutions. We argue that international

${ }^{1}$ The policy indicators that comprise the Gallego-Loayza index of policy complementarities are related to openness, the black market premium, government consumption, financial development, life expectancy, and education. In their last period of estimation, 1986-1998, the countries with a value of 1 in the policy complementarities dummy variable are Belgium, Chile, Ireland, Korea, the Netherlands, the Philippines, and Thailand. 
trade and international financial integration would lead to higher growth in countries with high-quality institutions.

The paper is divided in six sections. Section 1 is the Introduction. In section 2 we discuss the empirical strategy, while section 3 presents the main determinants of growth and the economic implications for Chile. We compare the performance of Chile in the 1980s and 1990s and establish the determinants of the economy's improvement. Section 4 discusses the policy complementarities as a determinant of economic growth. Section 5 presents different scenarios of policy improvement to show how much growth would increase. Section 6 concludes.

\section{Empirical Methodology}

The present section begins with a brief description of the estimation method used to obtain our parameters of interest. Specifically, we use the GMM-IV system estimator for dynamic panel data (Arellano and Bover, 1995; Blundell and Bond, 1998), which is suitable for our regression analysis by dealing with unobserved effects and endogenous regressors. ${ }^{2}$ We then present a succinct discussion on the data used to proxy the determinants of growth.

\subsection{Econometric Methodology}

Our growth analysis is based on a pooled data set of cross-country and time-series observations (5-year period observations for 78 countries over the 1970-2000 period). We use the generalized method of moments (GMM) estimator for dynamic panel data models (Arellano and Bond, 1991; Arellano and Bover, 1995; Blundell and Bond, 1998), which accounts for unobserved country- and time-specific effects and likely endogenous regressors.

Our main goal is to estimate the following variation of the standard growth regression (see Loayza, Fajnzylber, and Calderón, 2005):

$$
y_{i, t}-y_{i, t-1}=\alpha y_{i, t-1}+\beta^{\prime} X_{i, t}+\eta_{t}+\mu_{i}+\varepsilon_{i, t},
$$

where $\eta_{t}$ is a period-specific effect that controls for global shocks that affect the growth performance of countries in the sample, and $\mu_{i}$ represents unobserved country-specific effects and thus accounts for growth determinants that are idiosyncratic to the country and potentially correlated with the explanatory variables.

The GMM estimator deals with unobserved time effects by including period-specific intercepts; it handles country effects by differencing and

\footnotetext{
${ }^{2}$ This section draws heavily from Loayza, Fajnzylber, and Calderón (2005) and Calderón, Loayza, and Schmidt-Hebbel (2004).
} 
instrumentation given the dynamic specification of the model. The method also accounts for joint endogeneity by assuming that the explanatory variables are weakly exogenous. In sum, we identify our estimated parameters by assuming that future realizations of the error term do not affect current values of the explanatory variables, that the error term, $\varepsilon$, is serially uncorrelated, and that changes in the explanatory variables are uncorrelated with the unobserved country-specific effect.

This set of assumptions allows us to build moment conditions that set up our optimization problem and then to estimate the vector of parameters. Previous values of both levels and differences of the explanatory and dependent variables are used as instruments of these moment conditions. Since we are usually dealing with overidentified models, this method allows for specification testing through a Sargan-type test. Appendix A contains a detailed description of the methodology.

\subsection{Data Sources}

We estimate growth regressions on pooled cross-country and time-series data covering seventy-eight countries over the period 1970-2000. The data are organized in nonoverlapping five-year periods and each country has at most six observations (see appendix B for the list of countries). In what follows, we describe the definition and sources of the variables used in our growth regression analysis. Table B1 in appendix B contains the full description of the variables used in the paper; tables B2 and B3 provide descriptive statistics and correlation analysis between growth and its determinants.

We define our dependent variable as the growth rate of real per capita gross domestic product (GDP), measured as the five-year average of the log differences of per capita output. In turn, per capita output is measured as GDP divided by the total population (in 1985 PPP-adjusted US dollars) as in Loayza et al. (2005), and it is constructed using Summers and Heston (1991) and World Bank (2003). Our set of growth determinants can be classified into four groups, following Loayza et al. (2005): transitional convergence, structural policies and institutions, stabilization policies, and external conditions. Within the group of structural policies and institutions, we devote special attention to openness to international goods and capital markets.

Regarding the first group, transitional convergence, we use the initial value of GDP per capita (in logs) for the five-year period as our proxy for conditional convergence. We test whether the initial position of the economy is important for its subsequent growth, all things equal.

The second group, structural policies and institutions, is represented both theoretically and empirically by a wide array of economic policy determinants of growth. In the present paper, we consider the areas of education and human capital (Lucas, 1988), financial development (Levine, 1997), the government burden (Fischer, 1993; Engen and Skinner, 1996), governance (Knack and Keefer, 1995; Kaufmann, Kraay and Zoido-Lobatón, 1999), trade openness (Edwards, 1998; Wacziarg and Welch, 2003), and financial openness (Quinn, 1997; Bekaert, 
Harvey, and Lundblad, 2001, 2005; Calderón, Loayza, and Schmidt-Hebbel 2004). Of these, education is approximated by the gross rate of enrollment in secondary school, which is the ratio of the number of students enrolled in secondary school to the number of persons of the corresponding age. ${ }^{3}$ Barro and Lee (2001) -our source of information- suggest that this flow measure reflects current policies on human capital investment more than stock measures associated with education attainment of the adult population or life expectancy. Financial depth is proxied by the ratio of private domestic credit supplied by private financial institutions to GDP. Here we focus on credit from and to the private sector because their incentives to perform efficiently are clearer than the public sector's incentives. Our measure of financial depth is taken from Beck, Demirgüç-Kunt, and Levine (2000). We measure government burden as the ratio of general government consumption to GDP, using data from the World Bank (2003). ${ }^{4}$ We use consumption expenditure by the government as a proxy for two reasons: first, data on government expenditure categories are inconsistent, and, second, public wages arguably explain most of government consumption expenditure. In the case of governance, we use the first principal component of the following indicators: prevalence of law and order, quality of the bureaucracy, absence of corruption, and accountability of public officials. All these variables are taken from the International Country Risk Guide (ICRG) published by the Political Risk Services Group and constructed by Loayza et al. (2005).

The last two structural policies that we include are associated with the outward orientation of the economy. Here we consider the openness of the economy to international markets of goods and capital. First, we measure trade openness by the volume of trade (real exports and imports) over GDP, adjusted for the size of the country (proxied by its area and population), geography (whether the country is landlocked), and natural resources (whether it is an oil exporter). All these data are from the World Bank (2003) and the Global Development Network (2002). The rationale for using this measure is that fluctuations in the variable measured are attributed to trade policy instead of to structural features of the country. ${ }^{5}$ Second, we measure of financial openness by the ratio of equitybased foreign liabilities to GDP (Lane and Milesi-Ferretti, 2003):

$$
\mathrm{EQIFI}_{i, t}=\frac{\mathrm{PEQL}_{i, t}+\mathrm{FDIL}_{i, t}}{\mathrm{GDP}_{i, t}} .
$$

\footnotetext{
${ }^{3}$ Note that by construction, this rate could be greater than 100 , as a result of repeating and late enrollment.

${ }^{4}$ This variable is used as a proxy for government burden in Barro (1991), Barro and Sala-i-Martin (1995), Easterly, Loayza, and Montiel (1997), and Bekaert, Harvey, and Lundblad (2001).

${ }^{5}$ For instance, it has been argued that (a) small countries depend more on international trade than large countries, (b) oil-exporting countries can have large trade volumes and, simultaneously, impose high tariff barriers, and (c) landlocked countries face larger transaction costs and thus trade less than coastal countries (Loayza et al., 2005).
} 
Our equity-based measure of financial integration, $\mathrm{EQIFI}_{i t}$, is the sum of the stocks of portfolio-equity and foreign direct investment liabilities, PEQL and FDIL respectively. We update the figures from Lane and Milesi-Ferretti (2001) for our sample of countries using data from the Balance of Payments Statistics published by the International Monetary Fund (IMF).

With regard to our third group of growth determinants, we have evidence that stabilization policies have an impact not only on growth in the short term, but also on the long-run performance of the economy (Fischer, 1993). Our first proxy of macroeconomic stabilization is the consumer price index (CPI) inflation rate, with high inflation being associated with other bad macroeconomic policies such as excessive fiscal deficits and a high black market premium (see Loayza et al. 2005). Our source of information is the World Bank's World Development Indicators. A second variable -an index of real exchange rate overvaluationproxies the degree of external imbalances in the economy. This variable may capture the effects of monetary and exchange rate policy on the misallocation of resources between traded and nontraded sectors. See Table A2 for the construction of this variable and our data sources.

Finally, our fourth set of variables proxies the role of external conditions on the growth performance across countries. The regressions include terms-oftrade shocks, to capture shifts in the international demand for a country's exports and its input costs, and period-specific dummies, which capture the impact of other global shocks to growth across countries.

\section{Baseline Results}

The previous section outlined the different determinants of economic growth that we use in our regression analysis, as well as the estimation method used. We now describe the main result of our baseline growth regression. Here we use our sample of seventy-eight countries over the 1970-2000 period, organized in non-overlapping five-year periods, to estimate our growth regression equation using the GMM-system estimator developed by Arellano and Bover (1995) and Blundell and Bond (1998). This estimator accounts for econometric problems not corrected by conventional methods, such as unobserved country- and time-specific effects and the likely endogeneity of some growth determinants.

The first column of Table 1 presents our estimated baseline regression. In rest of this section, we describe our main findings, with the results organized according to the classification of the growth determinants specified in section 3 . First, we find a negative and significant coefficient for the log of initial output per capita in all specifications. This implies that there is evidence of conditional convergence -that is, poorer countries may exhibit higher growth rates than richer countries as a result of decreasing returns to accumulative factors. Thus other 
TABLE 1

DETERMINANTS OF ECONOMIC GROWTH: REGRESSION ANALYSIS ${ }^{a}$

\begin{tabular}{|c|c|c|c|}
\hline Variable & $\begin{array}{c}\text { Baseline regression } \\
\text { (1) }\end{array}$ & $\begin{array}{l}\text { Nonlinearieties in } \\
\text { financial openness } \\
\text { (2) }\end{array}$ & $\begin{array}{c}\text { Nonlinearieties in } \\
\text { trade openness } \\
\text { (3) }\end{array}$ \\
\hline Constant & $\begin{array}{c}18.041 * * \\
(0.36)\end{array}$ & $\begin{array}{l}30.674 * * \\
(5.60)\end{array}$ & $\begin{array}{l}11.777 * * \\
(1.69)\end{array}$ \\
\hline $\begin{array}{l}\text { Transitional convergence } \\
\text { Initial GDP per capita (in logs) }\end{array}$ & $\begin{array}{c}-0.085^{* *} \\
(0.01)\end{array}$ & $\begin{array}{c}-0.418 * \\
(0.23)\end{array}$ & $\begin{array}{c}-0.273^{* *} \\
(0.08)\end{array}$ \\
\hline $\begin{array}{l}\text { Structural policies } \\
\text { Human capital }\end{array}$ & $\begin{array}{l}1.553 * * \\
(0.02)\end{array}$ & $\begin{array}{l}0.698 * * \\
(0.14)\end{array}$ & $\begin{array}{l}1.450^{* *} \\
(0.08)\end{array}$ \\
\hline Financial depth & $\begin{array}{l}0.113^{* *} \\
(0.02)\end{array}$ & $\begin{array}{l}0.468^{* *} \\
(0.14)\end{array}$ & $\begin{array}{l}0.855^{* *} \\
(0.10)\end{array}$ \\
\hline Institutions & $\begin{array}{l}0.259^{* *} \\
(0.01)\end{array}$ & $\begin{array}{l}0.442 * * \\
(0.09)\end{array}$ & $\begin{array}{l}0.194 * * \\
(0.03)\end{array}$ \\
\hline Government consumption ( $\%$ of GDP) & $\begin{array}{l}-3.105^{* *} \\
(0.09)\end{array}$ & $\begin{array}{l}-3.085^{* *} \\
(0.19)\end{array}$ & $\begin{array}{l}-2.721 * * \\
(0.09)\end{array}$ \\
\hline \multicolumn{4}{|l|}{ Stabilization policies } \\
\hline Inflation rate & $\begin{array}{l}-2.351^{* * *} \\
(0.06)\end{array}$ & $\begin{array}{c}-4.328 * * \\
(0.78)\end{array}$ & $\begin{array}{l}-1.401 * * \\
\quad(0.33)\end{array}$ \\
\hline Real exchange rate overvaluation & $\begin{array}{c}-0.013 * * \\
(0.00)\end{array}$ & $\begin{array}{r}-0.004 \\
(0.00)\end{array}$ & $\begin{array}{c}-0.011^{* *} \\
(0.00)\end{array}$ \\
\hline \multicolumn{4}{|l|}{ Openness: } \\
\hline Trade openness & $\begin{array}{l}1.338 * * \\
(0.03)\end{array}$ & $\begin{array}{l}0.767 * * \\
(0.15)\end{array}$ & $\begin{array}{l}0.697 * * \\
(0.13)\end{array}$ \\
\hline Financial openness & $\begin{array}{l}0.851^{* *} \\
(0.09)\end{array}$ & $\begin{array}{l}0.699^{*} \\
(0.42)\end{array}$ & $\begin{array}{l}0.003 \\
(0.14)\end{array}$ \\
\hline \multicolumn{4}{|l|}{ Interaction between openness and institutions } \\
\hline Openness * Institutions & $\ldots$ & $\begin{array}{l}0.817 * * \\
(0.25)\end{array}$ & $\begin{array}{l}0.854 * * \\
(0.07)\end{array}$ \\
\hline Openness * (Institutions**2) & $\begin{array}{c}\ldots \\
(0.10)\end{array}$ & $-0.253 * *$ & $\cdots$ \\
\hline \multicolumn{4}{|l|}{ External conditions: } \\
\hline Terms-of-trade shocks & $\begin{array}{l}0.032 * * \\
(0.00)\end{array}$ & $\begin{array}{l}0.026 * * \\
(0.01)\end{array}$ & $\begin{array}{l}0.044 * * \\
(0.00)\end{array}$ \\
\hline \multicolumn{4}{|l|}{ Period shifts } \\
\hline $\begin{array}{l}\text { 1976-80: } \\
\text { 1981-85: } \\
\text { 1986-90: } \\
\text { 1991-95: } \\
\text { 1996-2000: }\end{array}$ & $\begin{array}{l}-0.463^{* *} \\
-2.362^{* *} \\
-1.565^{* *} \\
-2.309^{* *} \\
-2.410^{* *}\end{array}$ & $\begin{array}{l}-0.066 \\
-1.960 * * \\
-1.433^{*} * \\
-1.708^{*} * \\
-2.123^{*} *\end{array}$ & $\begin{array}{l}-0.474 * * \\
-2.550 * * \\
-1.820 * * \\
-2.473 * * \\
-2.383 * *\end{array}$ \\
\hline \multicolumn{4}{|l|}{ Summary statistics } \\
\hline No. countries & 78 & 78 & 78 \\
\hline No. observations & 371 & 371 & 371 \\
\hline \multicolumn{4}{|l|}{ Specification tests ( $\mathrm{p}$ values) } \\
\hline Sargan test of overidentification & $(0.46)$ & $(0.54)$ & $(0.49)$ \\
\hline Second-order autocorrelation & $(0.62)$ & $(0.91)$ & $(0.91)$ \\
\hline
\end{tabular}

* Statistically significant at the $10 \%$ level.

** Statistically significant at the $5 \%$ level.

Source: Authors' calculations.

a. The regressions are estimated using the GMM system estimator (Arellano and Bover, 1995; Blundell and Bond, 1998), based on a panel data sample of eighty-three countries over the period 1970-2000 (in non-overlapping five-year-average observations). Robust standard errors are in parentheses below the estimated coefficients. 
independent variables will affect the long run level of output, but the growth rate will be affected only in the transition to the new steady state. ${ }^{6}$

Second, the literature focuses on both the direct and indirect roles of education in explaining long-run growth. Education, as a factor of production, leads to higher growth; it complements physical capital (Acemoglu and Zilibotti, 2001) and natural resources (De Gregorio and Bravo-Ortega, 2005); and it improves the ability of countries to either innovate or adapt technologies (Coe and Helpman, 1995; Keller, 2004). Our estimates indicate that countries with high education levels display a higher growth rate than countries with low education levels. If the enrollment rate of secondary schooling in Chile increased from 70 percent (the average in the period 1996-2000) to 100 percent (the level observed in Switzerland over the same period), the growth rate would increase 0.60 percentage points per year. This surge in education would take about eleven years given the historic growth rate of secondary schooling in Chile.

Third, the literature provides ample evidence that financial depth promotes growth. ${ }^{7}$ Financial systems may help allocate resources and diversify risks, among other things. Our measure of financial depth -namely, the ratio of domestic credit to the private sector relative to GDP- shows a positive and significant relation with economic growth. This result is consistent with the findings of De Gregorio (1999) and Levine, Loayza, and Beck (2000). That is, the growth rate will be higher in countries with well developed financial systems. According to our estimates, a surge in domestic credit to the private sector in Chile from the average level displayed in 1996-2000 (65.4 percent of GDP) to the levels displayed by Canada and Ireland (approximately 83 percent of GDP, which represents the seventy-fifth percentile of the world distribution in financial development) would raise Chile's growth rate by 0.03 percentage points. An abrupt reform of the financial system in Chile that increased its financial depth to the levels exhibited by the United Kingdom (121 percent of GDP, at the ninetieth percentile) or Korea (144 percent of GDP, at the ninety-fifth percentile) would increase its growth rate by 0.07 and 0.10 percentage points a year, respectively.

Fourth, we find that government consumption (relative to GDP) has a negative and significant influence on the growth rate of the economy. This shows that the government's participation in economic activity imposes a heavy burden through high taxes and an inefficient allocation of its revenues. Average government spending in Latin America was around 13 percent of GDP in 19962000 (excluding Chile). If this were reduced to the levels observed in Chile during the same period (10.8 percent of GDP), the region's growth rate would increase by 0.30 percentage points. The growth benefits would be even larger for countries with a higher level of government consumption, such as Brazil and Colombia with around 18-20 percent of GDP.

\footnotetext{
${ }^{6}$ In the rest of the paper, when we talk about the growth rate we mean the average growth rate during the transitional dynamic period.

${ }^{7}$ See Levine (1997) for a thorough survey of the theoretical and empirical literature on the subject.
} 
Fifth, the quality of institutions proves to be a significant determinant of economic growth across countries. Consistent with earlier evidence (Mauro, 1995; Knack and Keefer, 1995), we find that the growth rate should be higher in countries with better institutions (that is, lack of corruption, prevalence of law and order, high democratic accountability, and high quality bureaucrats). Our aggregate index of institutions (that is, the principal components of several dimensions of governance) fluctuates between -3.26 and 3.47, with higher values corresponding to countries with better institutions. In 1996-2000, the level of institutional quality in Chile was 1.4; this is the highest value observed among Latin American countries, and it ranks in the sixty-eighth percentile of the world distribution. Our estimates suggest that raising institutional quality in Chile to the seventyfifth percentile (on par with Japan) would lead to an increase in the economy's growth rate of 0.20 percentage points a year. The gains in growth would be even higher -around 0.40 and 0.50 percentage points, respectively- if the level of institutional quality in Chile were to reach the levels of the ninetieth percentile (Austria, Norway, and Switzerland) or the ninety-fifth percentile (Canada, Denmark, the Netherlands, and Sweden). While Chile outperforms countries with similar levels of income per capita, its institutional quality still lags significantly behind that of advanced economies.

Sixth, we analyze the impact of openness to international trade of goods and assets on economic growth. We focus first on the impact of trade openness on economic performance. The literature attributes the positive growth effect of trade openness to an expansion of the potential market, increased specialization, and improvements in technological diffusion and managerial skills stemming from stronger interaction with foreign firms. In our regression analysis, we find a positive and significant relation between trade openness and economic growth; that is, a more outward orientation in the trade of goods may lead to higher growth. If the adjusted coefficient of trade openness in Chile were to increase to the levels observed in South Korea (that is, if it doubled), the economic growth rate of the country would increase by 0.34 percentage points. Moreover, if this "policy component" of trade openness in Chile increased to the levels of the ninetieth percentile (Ireland and the Philippines) or the ninety-fifth percentile (Canada and Thailand), the country's growth rate would rise by 0.70 and 0.90 percentage points per year.

A recent wave of empirical research on the relation between financial openness and growth reports mixed results so far. Theoretically, the impact of financial openness on growth is also inconclusive. Some researchers argue that greater openness to world capital markets may allow a higher degree of risk sharing and, hence, promote higher growth through production specialization and a more efficient allocation of capital (Acemoglu and Zilibotti, 1997). In addition, financial openness may facilitate capital flows to scarce countries and enhance domestic financial systems through greater competition and the import of financial services (Klein and Olivei, 1999; Levine, 2001). Other analysts, however, argue that financial openness can hurt growth in the presence of distortions (Eichengreen, 2001) or in countries with weak institutions and policies 
(Boyd and Smith, 1992). We include the ratio of equity-based foreign liabilities to GDP in our regressions as a proxy of financial openness and we find that its coefficient is positive and significant. This implies that the growth rate will be higher in countries with a higher degree of international financial integration. According to our estimates, if the ratio of foreign liabilities to GDP in Chile (which averaged 53 percent of GDP in 1996-2000) rose to the levels of Austria or the United Kingdom (73 percent of GDP, in the ninetieth percentile of the world distribution), then its growth rate would increase by 0.20 percentage points.

Turning now to the category of stabilization policies, we begin our evaluation with the relation between price instability and growth. The inflation rate is our proxy of price instability, as it is a reliable outcome measure of good or bad macroeconomic policies, and it has become an indicator of macroeconomic instability in empirical research (see Fischer, 1993; Easterly, Loayza, and Montiel, 1997). Our estimated coefficients suggest that inflation may harm economic growth. The growth benefits that Chile can reap are small given that the country has stabilized its inflation at low levels. However, the growth gains from reducing inflation are greater for other Latin American countries. For instance, if Ecuador were to reduce its inflation rate from an average 40 percent in 1996-2000 to the levels observed in Chile during the same period (around 4.7 percent per year), its growth rate would increase by 0.70 percentage points per year. The growth rates in Colombia and Venezuela could increase by 0.20 and 0.50 percentage points, respectively, if they were to reach the inflation rate of Chile.

Our second proxy in this category is the index of real exchange rate overvaluation. This variable captures the distortions introduced by macroeconomic policies in the allocation of resources between traded and nontraded sectors. Empirically, we find that an overvaluation of the real exchange rate hinders economic growth. According to the overvaluation index computed in Loayza et al. (2005), the Chilean peso was slightly overvalued relative to the U.S. dollar in the 1996-2000 period. ${ }^{8}$ If Chile were to eliminate this misalignment (reaching an index of 100), its growth would increase by 0.07 percentage points a year. Growth gains would be even larger in countries with higher degrees of overvaluation. For instance, if Australia reduced its real exchange rate overvaluation to the levels displayed by Chile -that is, from an index of 127.1 in 1996-2000 to $105.7-$ its growth rate would rise by 0.30 percentage points.

Finally, we find that external conditions can also affect economic growth across countries. This category is proxied by terms-of-trade shocks and periodspecific shifts. First, we find that growth is enhanced by favorable terms-of-trade shocks. This evidence is consistent with the positive impact of an increase in the terms of trade on our demand for exports. Second, the negative coefficient estimates of our period-specific dummies is consistent with the growth slowdown experienced by the world economy after 1973.

${ }^{8}$ Loayza et al. (2005) follow the methodology proposed by Dollar (1992) to construct the index. The average value of the real exchange rate overvaluation index for Chile in 1996-20000 was 105.6, which represents a 5.6 percent overvaluation. 


\section{Policy Complementarities and Economic Growth}

One of the puzzles in the analysis of economic reforms is why they have triggered higher growth in some economies but not in others. Gallego and Loayza (2002) credit policy complementarities for Chile's high economic growth and for the profitability of the country's reforms. In other words, it is not just good policies, but good combinations of policies, that could help stimulate growth. The effect of some variables on economic growth depends on the level of other variables.

Gallego and Loayza (2002) use a dummy variable to measure policy complementarities; it takes the value of one if the levels of certain structural variables are above the world median and zero otherwise. ${ }^{9}$ This variable would measure the existence of policy complementarities, that provides information on whether a country has surpassed certain threshold in the policy areas of education, financial development, openness to trade and stabilization. However, it does not provide information on the magnitude of the interaction among these individual policies. For instance, from their work we cannot infer whether the impact of trade policies on growth is higher when interacted with education, more liquid domestic financial sector or better quality of institutions. This information may prove useful for economic authorities in order to prioritize critical policy areas. Closing gaps in those areas may enhance the benefits of trade openness and may lead to significant growth improvements.

A number of papers in the literature attempt to determine the effects of policy complementarities on economic growth. Given that policies are inter-related in complex ways, there is a wide variety of interactions that could be evaluated. For that reason, the empirical and theoretical literature focuses on specific complementarities among policy areas. For instance, Levin and Raut (1997) show the existence of policy complementarities between human capital and the exportable sector for a sample of semi-industrial countries. Ok (2004) shows that the success of outward-orientation policies in South Korea may be attributed to active investment and industrial policies. Bolaky and Freund (2004) find that the impact of openness to trade on growth is negligible in economic environments with excessive regulation. Other works, however, find that the growth effects of high foreign direct investment depend directly on the level of human capital in the economy (Borensztein et al., 1998; De Gregorio, 1999) and the degree of domestic financial development (Alfaro et al., 2004). In addition, Edison et al. (2002) and Klein (2003) assess the importance of initial conditions, human capital, and domestic financial depth on the relation between the growth rate and openness to international financial markets. ${ }^{10}$

\footnotetext{
${ }^{9}$ Specifically, the constructed dummy variable takes the value of one if human capital (years of education and life expectancy), financial depth (ratio of private credit to the domestic sector), trade openness, and stabilization policies are above the world median. In the case of stabilization policies, government consumption and the black market premium should be below the median.

${ }^{10}$ Calderón and Fuentes (2006) are undertaking a comprehensive analysis of the complementarities between outward-orientation policies (both in the international market for goods and assets) and several structural and stabilization policies. Early evidence from this work in progress shows that openness to trade and the access to world capital markets are highly complementarily with a policy index.
} 
Again, the purpose of this paper is to illustrate the impact on growth of some important policy complementarities. To analyze all the possible interactions among policies is almost impossible (due to problems with degrees of freedom and unavailability of data) and is beyond the scope of the present paper. Specifically, this section will concentrate on the interactions between the quality of institutions and policies that promote trade and financial openness.

The regressions presented in the first column of Table 1 -like most of the growth regression in the empirical literature- assume that the effect of trade openness or financial openness on economic growth is the same for Chile, Australia, Pakistan, and Malawi, that is, the coefficients are constant for each country. In all likelihood, however, this effect will be influenced by the quality of institutions in each country.

\subsection{Financial Openness and Institution Quality}

As indicated above, the idea that financial openness enhances growth has not been empirically demonstrated. The current state of the art establishes that under certain conditions, capital account openness has a positive impact on economic growth. Column 2 of Table 1 presents the effect of the interaction between financial openness and institutional quality on economic growth. This exercise complements the evidence on how institutional quality affects the impact of financial openness on growth (Klein, 2003) and the financial aid flows on growth (Burnside and Dollar, 2000).

Our estimations show that capital account openness enhances economic growth in countries with high quality institutions, which is consistent with Klein's (2003) findings. Figure 1 exhibits the impact of a one-standard-deviation increase of financial openness (that is, an increase of 24 percent of the coefficient external liabilities over GDP) on growth for countries with different levels of institutions. The figure shows that financial openness has a negative impact on economic growth in countries with weak institutions (identified as countries whose institutional quality lies in the lowest quintile of the distribution). Thus, the growth response to an increase of one standard deviation in financial openness fluctuates between -0.01 and -0.60 percentage points per year for countries with weak institutions. Countries with an average annual loss in growth between 0.01 and 0.20 percentage points, we found Peru (0.02 percentage points), Honduras (0.04 percentage points), Paraguay ( 0.07 percentage points), Indonesia ( 0.09 percentage points), and Colombia (0.14 percentage points). Countries with even weaker institutions, such as Togo, Nigeria, Haiti, and Niger, present average annual growth losses above 0.40 percentage points.

The impact of increased financial openness becomes positive for higher levels of institutional quality. In our sample, this is the case for countries above the twentieth percentile in the world distribution of institutional quality. The impact coefficient of financial openness on growth increases for countries with stronger institutions, reaching a maximum of 0.32 percentage points higher growth when the degree of financial openness rises by one standard deviation (24 percent 
FIGURE 1

GROWTH EFFECTS OF HIGHER FINANCIAL OPENNESS

AS A FUNCTION OF THE LEVEL OF INSTITUTIONAL QUALITY

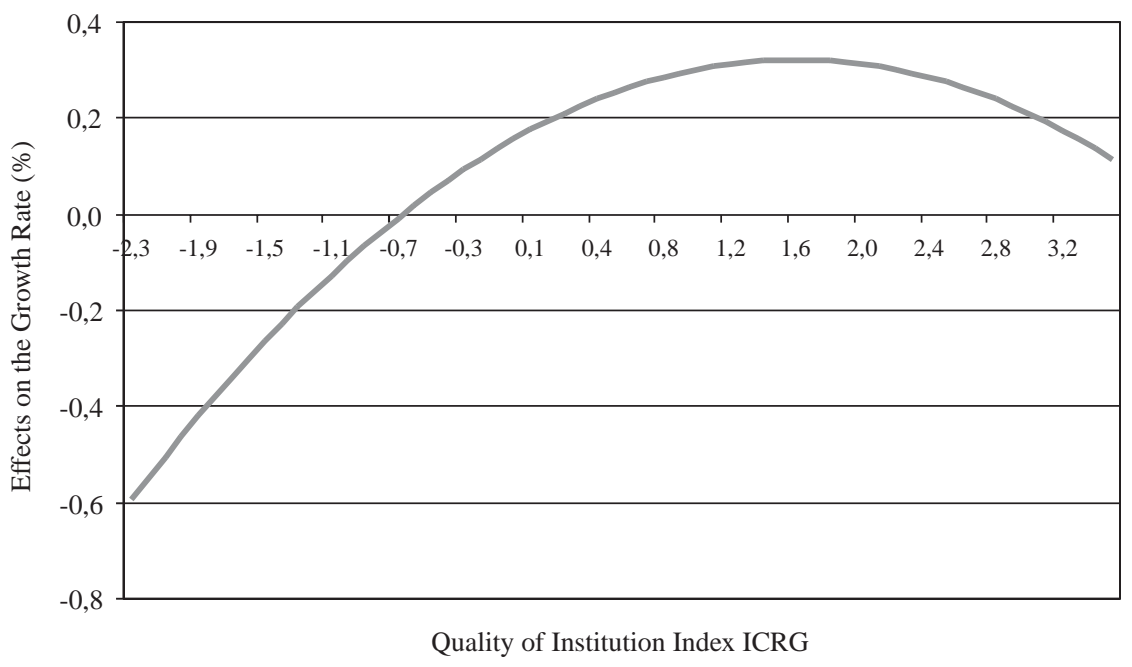

of GDP). According to our results, the highest impact occurs for Italy, Singapore, Chile, and South Korea, whose institutional quality lies in the seventieth percentile of the world distribution.

The nonlinear effect of financial openness on growth is consistent with the idea that financial openness tends to benefit middle income economies the most. More developed countries do not receive further benefits from opening their capital account, since they already have a well developed and internationally integrated financial market.

\subsection{Trade Openness and Institution Quality}

A large number of papers evaluate the relation between the degree of trade openness and economic growth. ${ }^{11}$ Rodríguez and Rodrik (2000), who use different measures of openness and trade policy, claim that those works do not find a robust relation between trade openness and economic growth. However, Wacziarg and Welch (2003) study episodes of trade liberalization to get a better picture of the effect of trade openness on growth. Their results suggest that the impact of trade openness on growth depends on the speed of capital accumulation (both physical and human), political stability, and the depth of the economic reforms.

Column 3 of Table 1 reports the estimated coefficients including the coefficient of the interaction between trade openness coefficient and institutional

\footnotetext{
${ }^{11}$ See, for example, Dollar (1992); Sachs and Warner (1995); Edwards (1998).
} 
quality. According to these results, trade openness has a larger impact on growth when institutional quality is higher, and this relationship is monotonic. Figure 2 similarly illustrates that trade openness has a negative impact on growth in countries with weak institutions (in the bottom 15 percent of the world distribution). This is the case for countries like Ghana, Haiti, Paraguay, Niger, Nigeria, Togo, and Zimbabwe. A one-standard-deviation increase in the degree of trade openness $(0.45)$ induces an average rise of 0.18 for a country in the twenty-fifth percentile (Brazil) and a 0.45 for the median country (Mexico).

FIGURE 2

GROWTH EFFECTS OF HIGHER TRADE OPENNESS

AS A FUNCTION OF THE LEVEL OF INSTITUTIONAL QUALITY

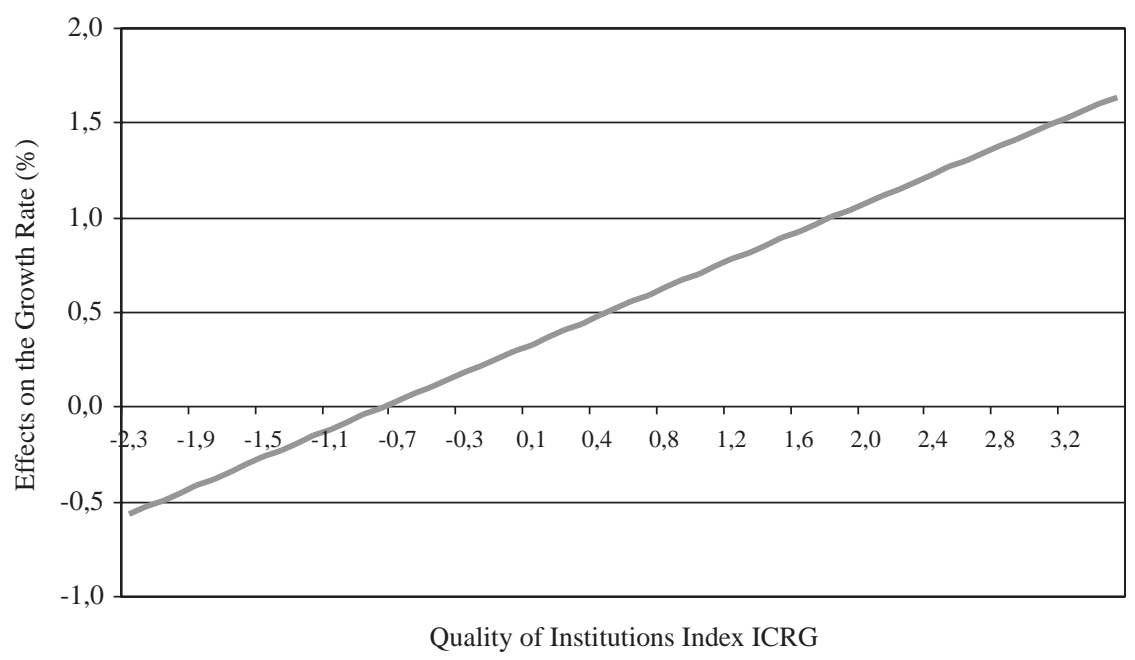

For the case of Chile, the growth rate would increase by 0.85 percentage points if the degree of openness (adjusted for scale factors and geography) rose by one standard deviation relative to the level observed in 1996-2000 (1.40). Finally for countries with a higher institutional quality than Korea (above the seventy-second percentile of the world distribution), the impact on growth of a one-standard-deviation increase in the degree of openness is larger than 1.0 percentage point per year.

\section{What Explains Growth? The Role of Economic Policy}

An important question that arises from the previous analysis is what factors explain Chilean economic growth. Was the rapid growth of the 1990s due to the 
convergence force, (that is, to the fact that Chile was relatively poor and thus tended to grow faster than richer countries), or did good policies play a central role? The answers to these questions can be derived from Table 2, which presents a comparison between the effective and projected growth rates for Chile and other regions in 1996-2000 and 1981-85. We obtained this projection using our baseline regression (column 1 of Table 1) and the regression that includes the complementarity between financial openness and institutions (column 2 of Table 1). Given the statistical significance of the interaction coefficients, we base our discussion of the results on the model with complementarities.

Our first conclusion after comparing the actual and projected rates is that the model is a good fit for forecasting the growth rate of Chile and the different regions presented in Table 2, with the exception of the East Asia. Chile grew 3.57 percent more in the second period than in the first, which is very closed to the 3.30 percent projected by the model. Here, the higher Chilean growth is due to structural policies, stabilization policies, and openness. Structural policies account for 1.90 percent of the explained variation of Chilean growth in that period, while openness policies (both trade and financial) explain 1.00 percentage point of the higher growth.

In 1981-85, the Chilean economy was in the middle of a reform process and a deep financial crisis. The economy began to experience the benefits of the reforms (namely, structural policies and openness) in the late 1980s and 1990s; this process, jointly with achievements in macroeconomic stability, could explain the rapid growth of that period. One might argue that this is an unfair comparison since the first period was characterized by a large international crisis, but we control for this effect in the regression through the external shock variables. Moreover, external shocks were also present in the second period.

Latin America also experienced a higher growth rate in the second period compared to the first one. As in the Chilean case the same group of variables (openness, structural policies and macroeconomic stabilization) explains the higher Latin American growth in the later period vis-à-vis the earlier one, whereas openness is the key variable explaining growth for East Asia and industrial countries in the late nineties. Some structural variables and real exchange rate overvaluation explain why the growth rate was not particularly high in the second period for the latter two groups of countries.

In summary Chile shows the highest increase in its growth rate (19962000 respect to 1981-1985) among the group of countries considered. Different group of policies that contribute to growth explains this result. This piece of evidence enhances the conclusion on the importance of policy complementarities. Another important issue is what this empirical model predicts for the future growth rate. For this exercise, we need to predict the right-hand-side variables of the regressions for each country. To do that we will consider different scenarios. 


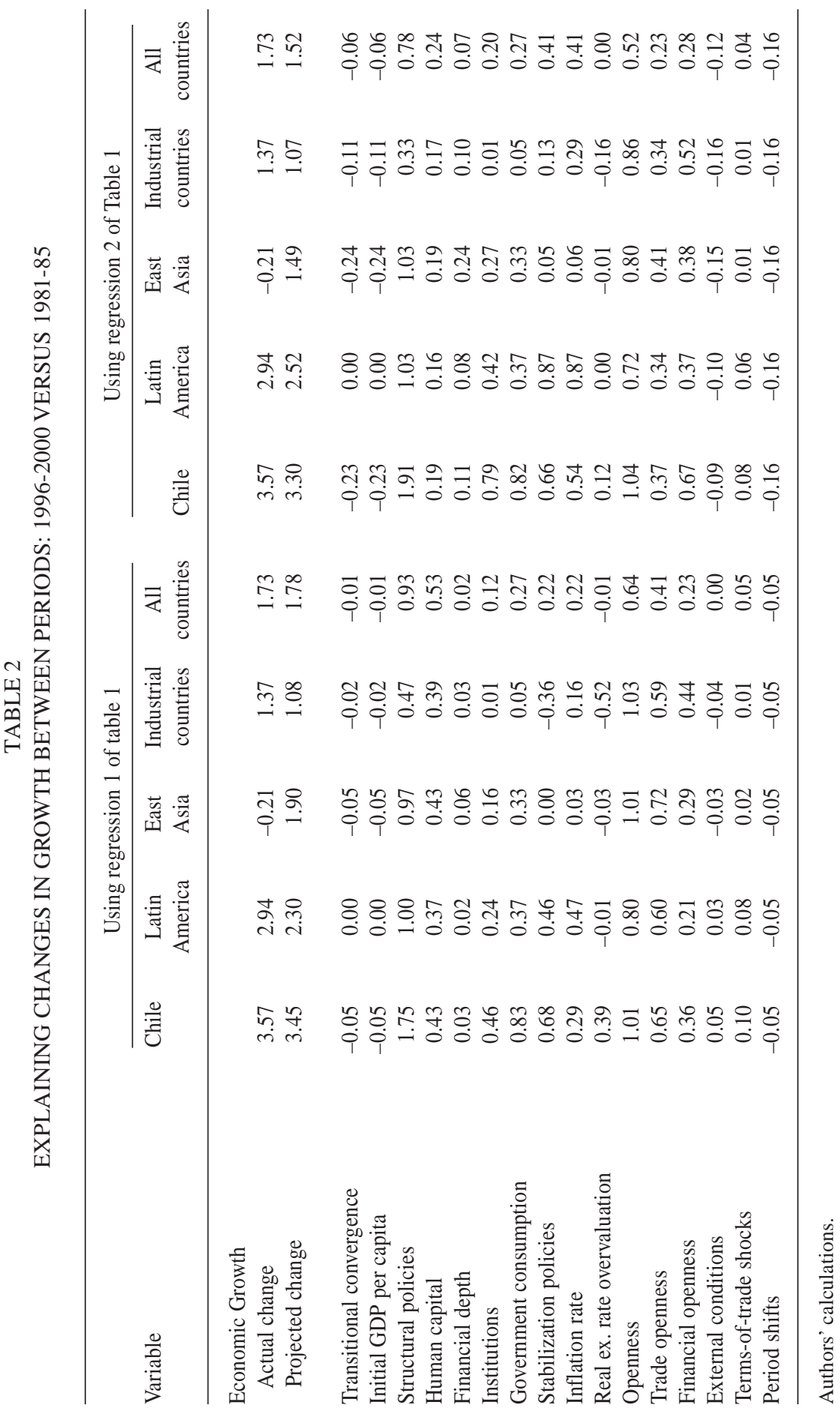




\subsection{Continuous Trend Scenario}

A first exercise is done under the assumption of a continuous trend for the explanatory variables, following the methodology of Loayza et al. (2005). This scenario forecast values for the right-hand-side variables that are in line with the historical trend. In the case of the reforms, this means that the economies will deepen their reform processes. The projection models could include deterministic trends (linear and quadratic), convergence terms, and moving average (MA) coefficients, among others. Table B4 in appendix B provides a more detailed explanation for each variable.

The results obtained under this scenario depend, in some cases, on strong assumptions. This is especially true for Chile, a country that has experienced one of the most accelerated reform processes in the world in the last thirty years. No better assumption is available, however, so we use this scenario for our baseline estimation.

The forecasted values for the variables related to structural reforms show that deepening economic policy at the previous trend would imply several things: (a) an increase in the secondary enrollment rate from 7 percent in 1996-2000 to almost 85 percent in 2006-10; (b) a rise in domestic credit to private sector from 42 percent of GDP in 1996-2000 to 52 percent of GDP in 2006-10; (c) an increase in the adjusted coefficient of openness of 5 percentage points of GDP; and (d) an increase in the external liabilities related to foreign investment and equity from 53 percent of GDP in 1996-2000 to 66 percent in 2006-10. On the other hand, the stabilization policy variables in this scenario would hold the inflation rate around 3 percent in 2006-10 (compared to an average inflation rate of 8 percent in 1996-2000), and it would keep the real exchange rate in line with the equilibrium path.

Thus, if and only if the variables followed the pattern described by the continuous trend scenario, Chile's growth rate would be 0.27 percentage points higher in the five-year period 2006-10 than in 1996-2000 (see Table 3). This is below the higher growth rate for East Asia in that period ( 0.47 percentage points) and barely better than Latin America ( 0.24 percentage points). Chile has historically introduced reforms at a faster pace than the rest of Latin America. Therefore, for the rest of the continent, the continuous trend scenario means a deepening of the reform process.

Of this 0.27 percentage point of higher growth rate for 2006-10, structural policies contribute 0.28 percentage point, while the macroeconomic stabilization efforts contribute only 0.10 percentage point. This low contribution from stabilization policies is due to the fact that the base for comparison is the 1990s, when the inflation rate was above 3 percent, whereas inflation is now stable at around 3 percent. These effects are partially cancelled by the convergence effect, since Chile has a higher initial per capita GDP than the rest of the region. 
TABLE 3

GROWTH FORECASTS UNDER A CONTINUOUS TREND SCENARIO: 2006-10 VERSUS 1996-2000a

\begin{tabular}{lrrrrr}
\hline Variable & Chile & $\begin{array}{c}\text { Latin } \\
\text { America }\end{array}$ & $\begin{array}{r}\text { East } \\
\text { Asia }\end{array}$ & $\begin{array}{r}\text { Industrial } \\
\text { countries }\end{array}$ & $\begin{array}{c}\text { All } \\
\text { countries }\end{array}$ \\
\hline Estimated growth rate, 1996-2000 (\%) & 2.70 & 1.05 & 1.80 & 2.62 & 1.64 \\
$\quad$ Projected change in growth (\%) & 0.27 & 0.24 & 0.47 & 0.14 & 0.21 \\
Expected growth rate, 2006-10 (\%) & 2.97 & 1.29 & 2.27 & 2.76 & 1.85 \\
& & & & & \\
Transitional convergence & -0.13 & -0.05 & -0.18 & -0.11 & -0.11 \\
$\quad$ Initial GDP per capita & -0.13 & -0.05 & -0.18 & -0.11 & -0.11 \\
& & & & & \\
Structural policies & 0.28 & 0.14 & 0.53 & 0.20 & 0.28 \\
$\quad$ Human capital & 0.15 & 0.11 & 0.11 & 0.14 & 0.13 \\
Financial depth & 0.07 & 0.06 & 0.06 & 0.06 & 0.07 \\
Institutions & 0.03 & 0.08 & 0.05 & 0.02 & 0.04 \\
$\quad$ Government consumption & -0.27 & -0.28 & -0.01 & -0.28 & -0.19 \\
$\quad$ Trade openness & 0.12 & 0.05 & 0.09 & 0.09 & 0.09 \\
Financial openness & 0.18 & 0.11 & 0.23 & 0.18 & 0.13 \\
$\quad$ & & & & & \\
Stabilization policies & 0.09 & 0.21 & 0.12 & 0.05 & 0.05 \\
$\quad$ Inflation rate & 0.07 & 0.21 & 0.12 & 0.00 & 0.04 \\
Real exch. rate overvaluation & 0.02 & 0.00 & 0.00 & 0.05 & 0.01 \\
& & & & & \\
External conditions & 0.03 & -0.06 & 0.00 & 0.00 & -0.01 \\
$\quad$ Terms-of-trade shocks & 0.03 & -0.06 & 0.00 & 0.00 & -0.01 \\
\hline
\end{tabular}

Authors' calculations.

a. The growth forecasts are computed using regression 2 of Table 1 .

\subsection{Sharp Progress Scenarios}

A second exercise makes projections under different scenarios of sharp progress in economic reforms. For those scenarios, the policy variables are assumed to take values above those found in the continuous trend scenario.

These scenarios assume a deepening of structural reforms in the following areas: education (an increase in the secondary enrollment), financial development (an increase in the ratio of private credit to GDP), trade openness, and financial openness. For the other variables (namely, inflation, real exchange rate overvaluation, institutions, and government consumption), we assume that the future value is the same as under the continuous trend scenario. We use four different sets of values to make our projections, which are presented as four different scenarios below. These four scenarios are useful for illustrating the growth rate that Chile could achieve if it accelerated the next stage of reforms. However, the speed of the reform process varies with the type of policy involved. 
Some of the scenarios simulated here could be reached relatively quickly, while others could take a number of years.

Table 4 presents our results under all four scenarios. The first scenario (which we call EME-90th percentile) projects how far Chile needs to progress in the areas of education, financial development, and trade and financial openness to reach the ninetieth percentile of the distribution of the group of emerging market economies, based on the values registered by those economies in 19962000. This scenario implies the following changes: (a) an increase in the rate of secondary enrollment from 70 to 85 percent (the level registered by Philippines in 1996-2000), which could be attainable for Chile at the beginning of the 20062010 period, given the trend in education data; (b) a doubling of the ratio of domestic credit to GDP, from 65 percent to the levels shown by Malaysia; (c) a rise in the level of openness (adjusted for size and geographical factors) to the levels shown by China and Mexico; and (d) essentially no change in the financial openness coefficient, given that Chile is already in the ninetieth percentile of the emerging market economies' distribution.

TABLE 4

GROWTH FORECASTS UNDER SHARP PROGRESS SCENARIOS: 2006-2010 VERSUS 1996-2000a

\begin{tabular}{|c|c|c|c|c|c|}
\hline \multirow[b]{2}{*}{ Variable } & \multirow[b]{2}{*}{$\begin{array}{l}\text { Continuous } \\
\text { trend scenario }\end{array}$} & \multicolumn{4}{|c|}{ Scenarios of sharp progress in economic reforms } \\
\hline & & $\begin{array}{l}\text { Emerging market } \\
\text { 90th percentile }\end{array}$ & $\begin{array}{l}\text { economies } \\
\text { Leader }\end{array}$ & $\begin{array}{l}\text { Industria } \\
\text { Average }\end{array}$ & $\begin{array}{l}\text { al economies } \\
\text { 75th percentile }\end{array}$ \\
\hline Estimated growth rate, 1996-2000 (\%) & 2.7 & 2.7 & 2.7 & 2.7 & 2.7 \\
\hline Projected change in growth $(\%)$ & 0.3 & 0.8 & 1.3 & 0.4 & 0.8 \\
\hline Expected growth rate, 2006-10 (\%) & 3.0 & 3.5 & 4.0 & 3.1 & 3.5 \\
\hline Transitional Convergence & -0.13 & -0.13 & -0.13 & -0.13 & -0.13 \\
\hline Structural Policies & 0.28 & 0.78 & 1.34 & 0.44 & 0.84 \\
\hline Human Capital & 0.15 & 0.13 & 0.26 & 0.30 & 0.36 \\
\hline Financial Development & 0.07 & 0.37 & 0.37 & 0.18 & 0.27 \\
\hline Trade Openness & 0.12 & 0.52 & 0.81 & 0.03 & 0.19 \\
\hline Financial Openness & 0.18 & 0.01 & 0.14 & 0.18 & 0.27 \\
\hline Stabilization Policies & 0.09 & 0.09 & 0.09 & 0.09 & 0.09 \\
\hline External Conditions & 0.03 & 0.03 & 0.03 & 0.03 & 0.03 \\
\hline
\end{tabular}

Authors' calculations.

a. The growth forecasts are computed using regression 2 of Table 1 .

The second scenario (EME-Maximum) contemplates an abrupt reform that would move Chile to the level of the emerging market leaders in the different policy areas considered. For education and domestic financial market 
development, Chile would need to achieve the levels of Korea (which has 100 percent secondary enrollment) and Thailand (where private credit to GDP is 140 percent). Based on the historical growth rates of those variables, we estimate that the reforms in education and the domestic financial market could be implemented at the beginning of the 2016-2020 and 2031-2035 periods, respectively. In the area of international trade, the goal would be to reach the level of Korea, which had a coefficient of openness equal to 85 percent of GDP in 2003. Finally, in the area of financial integration, this scenario calls for an increase in the ratio of external liability to GDP from 52 percent in 1996-2000 to 62 percent, which is the level of Malaysia in that period.

The third scenario (IND-average) requires accelerating the reforms in education, financial sector development, and trade and financial openness to reach the representative outcome of industrial economies. With regard to educational level, this scenario considers an increase of the secondary enrollment rate to the level of Canada (that is, above 100 percent), which could be reached by the 2016-2020 period if Chile follows its current trend in education. ${ }^{12}$ Deepening financial development implies raising private credit to 95 percent of GDP, which is the ratio for Portugal in 1996-2000. Chile's adjusted coefficient of trade openness is already similar to the average of industrial economies. In the case of financial integration, the level of external liabilities needs to reach 65 percent of GDP, which is the level for Austria and Finland in 1996-2000.

Our final scenario (IND-75th Percentile) projects what it would take for Chile to reach the level of the seventy-fifth percentile of the distribution of industrial economies. This is equivalent to obtaining the secondary enrollment rate observed in New Zealand, which was above 110 percent in 1960-2000; Chile could achieve this rate in the 2021-2025 period, given the observed trend in the data. In the area of financial development, Chile would need to increase private credit over GDP from 65 to 115 percent (the level of Sweden in 1996-2000). Considering the trend in the data, Chile could reach that level in the 2026-2030 period. Under this scenario, the adjusted trade openness coefficient would have to rise from 0.33 to 0.58 (Germany in 1996-2000), and financial integration should increase to 75 percent of GDP (Australia in 1996-2000)

Looking at this final exercise, our results tell us that Chile can grow between 0.3 to 1.3 percentage point faster per annum on the second half of this decade compared to the 1996-2000 period. However the efforts in terms of improving policies in several dimension is too big to be feasible in such a short period of time.

\footnotetext{
${ }^{12}$ The human capital variable was constructed using the secondary enrollment rate. The United Nations estimates this rate as the coefficient of the number of students enrolled in the secondary level divided by the age group that corresponds to that educational level. Given this definition, that rate of education could be higher than 100 percent, because of students who failed and are repeating the grade and because of the enrollment of student who are older or younger than the age group defined by the United Nations.
} 


\section{Concluding Remarks}

Based on estimations using a sample of seventy-eight countries for the 1970-2000 period, we found that policy complementarities are important for understanding the heterogeneous response of growth to both trade openness and financial openness. Thus, the variety of experiences across countries in terms of trade and capital account liberalization could be attributed to the different interactions in play between these outward-orientation policies and the quality of institutions (as well as other structural policies) in the country.

We can summarize our findings in three key points. First, the impact of financial liberalization on economic growth is negative for nations with weak institutions. Countries with strong institutions receive the largest benefit of trade and financial openness. The peak benefit, however, is obtained at different level of openness for each variable. This result is consistent with Calderón, Loayza, and Schmidt-Hebbel (2004), who find that trade and financial openness have a nonlinear effect on growth. Specifically, they find that financial openness most strongly favors middle income countries. The industrial nations gain little additional benefit because they are already integrated to financial markets.

Second, Chile has enjoyed a relatively high level of growth mainly as a result of a range of good policies. The most important are institution quality, financial openness, and macroeconomic stability. If Chile continues to deepen the reforms at the same pace observed in the data (in terms of both direction and intensity), the average annual growth rate for the five-year period 2006-2010 would be 0.27 percentage point higher than in the second five-year period of the previous decade.

Finally, deepening economic policies and reforms in areas like education, financial market development, and trade openness will provide the momentum for the economy to increase the growth rate in the transition a higher steady state. Specifically, deepening these policies will increase the average growth rate by 0.8 percentage point per annum for 2006-2010 compared to $1996-2000 .^{13}$

\footnotetext{
${ }^{13}$ Note that an annual growth rate of 2.7 percent (as experienced by Chile) in 1996-2000 would lead to a cumulative growth rate of approximately 14 percent over this 5 -year period. However, an increase in the growth rate of 80 basis points (to 3.5 percent predicted for 2006-10 under the scenario of $90^{\text {th }}$ percentile for EMEs) would generate a cumulative growth of 19 percent over this 5-year period.
} 


\section{APPENDIX A \\ ESTIMATION METHODOLOGY: THE GMM-IV SYSTEM ESTIMATOR ${ }^{14}$}

To estimate our growth regression equation, we have to deal with two problems. The first is the presence of unobserved country- and time-specific effects. The time affects are accounted for by the inclusion of period-specific dummy variables. In the case of country-specific effects, however, we cannot use common methods such as within-group estimators given the dynamic nature of our regression equation. The second problem we may face is the possibility of endogenous regressors in a dynamic panel data environment, and we need to control for possible inconsistent estimates resulting from simultaneity. To overcome these problems, we use the generalized method of moments (GMM) estimators developed for dynamic panel data models by Arellano and Bond (1991), Arellano and Bover (1995), and Blundell and Bond (1998). The GMM estimator for dynamic panel data controls for unobserved country-effects by expressing the regression equation in differences and/or instrumenting for these unobserved effects, and by using internal instruments (namely, lagged observations of the regressors) to control for endogeneity.

Once we accounted for time-specific effects, we can express our growth regression equation as follows:

$$
y_{i, t}=\alpha y_{i, t-1}+\beta^{\prime} X_{i, t}+\eta_{i}+\varepsilon_{i, t}
$$

To account for country-specific effects, we express equation A1 in first differences:

$$
y_{i, t}-y_{i, t-1}=\alpha\left(y_{i, t-1}-y_{i, t-2}\right)+\beta^{\prime}\left(X_{i, t}-X_{i, t-1}\right)+\left(\varepsilon_{i, t}-\varepsilon_{i, t-1}\right)
$$

As we said before, our set of instruments consists of previous observations of the explanatory and lagged dependent variables. ${ }^{15}$ The method thus only allows current and future values of the explanatory variables to be affected by the error term. In sum, this IV method assumes weak exogeneity (that is, our set of variables is not fully endogenous).

The GMM dynamic panel estimator assumes that (a) the error term, $\varepsilon$, is not serially correlated, and (b) the explanatory variables, $X$, are weakly exogenous (that is, the explanatory variables are assumed to be uncorrelated with future realizations of the error term). Hence, it establishes the following moment conditions:

\footnotetext{
${ }^{14}$ This appendix draws heavily from Loayza, Fajnzylber, and Calderón (2005).

15 The use of instruments should account for (a) the likely endogeneity of the explanatory variables and (b) the problem that, by construction, the new error term, $\varepsilon_{i, t}-\varepsilon_{i, t-1}$, is correlated with the lagged dependent variable, $y_{i, t-1}-y_{i, t-2}$.
} 


$$
E\left[y_{i, t-s} \cdot\left(\varepsilon_{i, t}-\varepsilon_{i, t-1}\right)\right]=0 \quad \text { for } s \geq 2 ; t=3, \ldots, T ; \text { and }
$$

(A4) $E\left[X_{i, t-s} \cdot\left(\varepsilon_{i, t}-\varepsilon_{i, t-1}\right)\right]=0 \quad$ for $s \geq 2 ; t=3, \ldots, T$.

The estimator -based on conditions A3 and A4- is the GMM difference estimator (Arellano and Bond, 1991). Although it outperforms other simpler panel data estimators, the GMM difference estimator has some significant statistical problems. It has been shown that previous levels of explanatory variables are weak instruments for equation $\mathrm{A} 2$ if these regressors are persistent over time (Blundell and Bond, 1998; Alonso-Borrego and Arellano, 1999). Specifically, the problem of weak instruments generates inefficient estimates (that is, the variance of the coefficients rises), and according to Monte Carlo experiments, it can yield inconsistent coefficients in small samples. ${ }^{16}$

To overcome the problems posed by the GMM difference estimator, we use an estimator that combines the regressions in differences and in levels in a system, as developed by Arellano and Bover (1995) and Blundell and Bond (1998). The instruments for the regression in differences are similar to the ones specified above, whereas the instruments for the regression in levels are the lagged differences of the corresponding variables. These instruments are appropriate if we assume that there is no correlation between the differences of the explanatory variables and the country-specific effect -although the correlation between the levels of the right-hand-side variables and the country-specific effect in equation A1 may be different from zero. This assumption results from the following stationarity property:

$$
\begin{aligned}
& E\left[y_{i, t+p} \cdot \eta_{i}\right]=E\left[y_{i, t+q} \cdot \eta_{i}\right] \text { and } \\
& E\left[X_{i, t+p} \cdot \eta_{i}\right]=E\left[X_{i, t+q} \cdot \eta_{i}\right] \text { for all } p \text { and } q
\end{aligned}
$$

This implies that for the second part of the system -that is, the regression in levels- we have the following additional moment conditions: ${ }^{17}$

$$
\begin{aligned}
& E\left[\left(y_{i, t-1}-y_{i, t-2}\right) \cdot\left(\eta_{i}+\varepsilon_{i, t}\right)\right]=0 \text { and } \\
& E\left[\left(X_{i, t-1}-X_{i, t-2}\right) \cdot\left(\eta_{i}+\varepsilon_{i, t}\right)\right]=0,
\end{aligned}
$$

\footnotetext{
${ }^{16}$ An additional problem with the simple difference estimator relates to measurement error: differencing may exacerbate the bias stemming from errors in the variables by decreasing the signalto-noise ratio (see Griliches and Hausman, 1986).

${ }^{17}$ Given that lagged levels are used as instruments in the difference specification, only the most recent difference is used as an instrument in the levels specification. Using other lagged differences would result in redundant moment conditions (see Arellano and Bover, 1995).
} 
where we use the moment conditions in equations A3, A4, A6, and A7 and employ a GMM procedure to generate consistent and efficient parameter estimates. The coefficient estimates and their asymptotic variance-covariance matrix is given by the following formulas:

$$
\hat{\theta}=\left(\bar{X}^{\prime} Z \hat{\Omega}^{-1} Z^{\prime} \bar{X}\right)^{-1} \bar{X}^{\prime} Z \hat{\Omega}^{-1} Z^{\prime} \bar{y} \text { and }
$$

$$
A V A R(\hat{\theta})=\left(\bar{X}^{\prime} Z \hat{\Omega}^{-1} Z^{\prime} \bar{X}\right)^{-1},
$$

where our vector of parameters of interest is $\theta=(\alpha, \beta), \bar{y}$ is the dependent variable stacked first in differences and then in levels, $\bar{X}$ is the explanatory-variable matrix including the lagged dependent variable $\left(y_{t-1}, X\right)$ stacked first in differences. For the regression in levels, $Z$ is the matrix of instruments derived from the moment conditions. Finally, $\hat{\Omega}$ is a consistent estimate of the variance-covariance matrix of the moment conditions. ${ }^{18}$

To prove the consistency of our GMM estimators -that is, to test whether the lagged values of the explanatory variables are valid instruments- we consider two specification tests (Arellano and Bond, 1991; Arellano and Bover, 1995). First, the Sargan test of overidentifying restrictions tests the joint validity of our instruments by analyzing the sample analog of the moment conditions used in the estimation process. The model is supported empirically if we fail to reject the null hypothesis. Second, we test whether the error term $\varepsilon_{i, t}$ is serially correlated. Here, our specification is valid if we fail to reject the null hypothesis of no higherorder serial correlation. ${ }^{19}$

\footnotetext{
${ }^{18}$ In practice, Arellano and Bond (1991) suggest a two-step procedure to obtain consistent and efficient GMM estimates. First, assume that the residuals, $\varepsilon_{i, t}$, are independent and homoskedastic both across countries and over time. This assumption corresponds to a specific weighting matrix used to get first-step coefficient estimates. Second, construct a consistent estimate of the variancecovariance matrix of the moment conditions with the residuals obtained in the first step, and use this matrix to reestimate the parameters of interest (that is, second-step estimates). Asymptotically, the second-step estimates are superior to the first-step ones insofar as efficiency is concerned.

${ }^{19}$ First-order serial correlation of the differenced error term is expected even if the original error term (in levels) is uncorrelated, unless the latter follows a random walk. Second-order serial correlation of the differenced residual indicates that the original error term is serially correlated and follows a moving average process at least of order one. This would reject the appropriateness of the proposed instruments (and would call for higher-order lags to be used as instruments).
} 


\section{APPENDIX B \\ SAMPLE OF COUNTRIES AND SOURCES OF DATA}

This appendix describes the data used in our analysis. We start with a list of the countries included in the sample. Table B1 contains the full description of the variables used in the paper. Tables B2 and B3 then provide descriptive statistics and correlation analysis between growth and its determinants. Finally, Table B4 describes the procedures used to forecast the variables for the continuous trend scenario.

Our sample covers seventy-eight countries over the period 1970-2000. The countries are listed here by group or region.

-Industrial Economies (22): Australia, Austria, Belgium, Canada, Denmark, Finland, France, Germany, Greece, Iceland, Ireland, Italy, Japan, the Netherlands, New Zealand, Norway, Portugal, Spain, Sweden, Switzerland, the United Kingdom, and the United States.

-Latin America and the Caribbean (21): Argentina, Bolivia, Brazil, Chile, Colombia, Costa Rica, Dominican Republic, Ecuador, El Salvador, Guatemala, Haiti, Honduras, Jamaica, Mexico, Nicaragua, Panama, Paraguay, Peru, Trinidad and Tobago, Uruguay, and Venezuela.

-East Asia and the Pacific (8): China, Indonesia, Republic of Korea, Malaysia, Papua New Guinea, the Philippines, Singapore, and Thailand.

-Middle East and North Africa (8): Algeria, Egypt, Israel, Jordan, Morocco, Syria, Tunisia, and Turkey.

-South Asia (4): Bangladesh, India, Pakistan, and Sri Lanka.

-Sub-Saharan Africa (15): Botswana, Burkina Faso, Côte d'Ivoire, Gambia, Ghana, Kenya, Madagascar, Malawi, Niger, Nigeria, Senegal, South Africa, Togo, Zambia, and Zimbabwe. 
TABLE B1

DEFINITION AND SOURCES OF THE VARIABLES USED IN THE REGRESSION ANALYSIS

\begin{tabular}{|c|c|c|}
\hline Variable & Definition & Sources of information \\
\hline GDP per capita & $\begin{array}{l}\text { Total GDP divided by the } \\
\text { population of a country. GDP is } \\
\text { expressed in } 1985 \text { PPP US\$. }\end{array}$ & $\begin{array}{l}\text { Summers and Heston (1991); } \\
\text { World Bank (2002). }\end{array}$ \\
\hline $\begin{array}{l}\text { Growth rate of GDP } \\
\text { per capita }\end{array}$ & $\begin{array}{l}\text { Log differences of GDP per } \\
\text { capita. }\end{array}$ & $\begin{array}{l}\text { Summers and Heston (1991); } \\
\text { World Bank (2002). }\end{array}$ \\
\hline Initial GDP per capita & $\begin{array}{l}\text { Value of GDP per capita at the } \\
\text { beginning of the period. GDP is } \\
\text { expressed in } 1985 \text { PPP US\$. }\end{array}$ & $\begin{array}{l}\text { Summers and Heston (1991); } \\
\text { World Bank (2002). }\end{array}$ \\
\hline $\begin{array}{l}\text { Investment in human } \\
\text { capital }\end{array}$ & $\begin{array}{l}\text { Secondary schooling enrollment } \\
\text { rate: number of students enrolled } \\
\text { in secondary education } \\
\text { (regardless of their age) relative } \\
\text { to total population of the } \\
\text { corresponding age group. }\end{array}$ & $\begin{array}{l}\text { World Development Network } \\
\text { (2002); World Bank (2002). }\end{array}$ \\
\hline Financial depth & $\begin{array}{l}\text { Ratio of domestic credit to the } \\
\text { private sector to GDP. }\end{array}$ & $\begin{array}{l}\text { Computed by Loayza, Fajnzylber, } \\
\text { and Calderón (2004) using data } \\
\text { from IMF's IFS, central bank } \\
\text { publications, and Penn-World } \\
\text { Database. Computations follow } \\
\text { the methodology of Beck, } \\
\text { Demigüç-Kunt, and Levine } \\
\text { (2000). }\end{array}$ \\
\hline Institutions & $\begin{array}{l}\text { First principal component of four } \\
\text { governance indicators: rule of } \\
\text { law, bureaucratic quality, } \\
\text { corruption, and democratic } \\
\text { accountability. }\end{array}$ & $\begin{array}{l}\text { Computed by Loayza, Fajnzylber, } \\
\text { and Calderón (2004) using data } \\
\text { from the International Country } \\
\text { Risk Guide (ICRG). }\end{array}$ \\
\hline $\begin{array}{l}\text { Government } \\
\text { consumption }\end{array}$ & $\begin{array}{l}\text { Ratio of real government } \\
\text { consumption to GDP (in logs). }\end{array}$ & World Bank (2002). \\
\hline CPI & Consumer price index $(1995=100)$. & $\begin{array}{l}\text { IMF, International Financial } \\
\text { Statistics. }\end{array}$ \\
\hline Inflation Rate & Annual growth rate of CPI. & $\begin{array}{l}\text { IMF, International Financial } \\
\text { Statistics. }\end{array}$ \\
\hline $\begin{array}{l}\text { Real exchange rate } \\
\text { overvaluation }\end{array}$ & $\begin{array}{l}\text { Real effective exchange rate, with } \\
\text { the level adjusted such that the } \\
\text { average for 1976-85 equals } \\
\text { Dollar's (1992) index of } \\
\text { overvaluation (based on the ratio } \\
\text { of actual to income-adjusted } \\
\text { Summers-Heston purchasing } \\
\text { power parity comparisons). }\end{array}$ & Easterly (2001). \\
\hline
\end{tabular}


(continuation Table B1)

\begin{tabular}{|c|c|c|}
\hline Variable & Definition & Sources of information \\
\hline Trade openness & $\begin{array}{l}\text { Residual of a regression of the } \\
\text { log of the ratio of exports and } \\
\text { imports (in 1995 US\$) to GDP } \\
\text { (in } 1995 \text { US\$) on the logs of area } \\
\text { and population, and dummies for } \\
\text { oil-exporting and landlocked } \\
\text { countries. }\end{array}$ & $\begin{array}{l}\text { Computed by Loayza, Fajnzylber } \\
\text { and Calderón (2004) using data } \\
\text { from World Development } \\
\text { Network (2002) and World Bank } \\
(2002) \text {. }\end{array}$ \\
\hline Financial openness & $\begin{array}{l}\text { Coefficient of the stock of foreign } \\
\text { liabilities (foreign direct } \\
\text { investment and portfolio } \\
\text { investment) as a percent of GDP. } \\
\text { Expressed in constant } 1995 \text { US\$. }\end{array}$ & $\begin{array}{l}\text { Lane and Milesi-Ferreti ( } 2001 \text {, } \\
\text { 2003); IMF, Balance of Payments } \\
\text { Statistics. }\end{array}$ \\
\hline Terms of trade & Terms-of-trade index $(1995=100)$ & $\begin{array}{l}\text { World Development Network } \\
\text { (2002); World Bank (2002). }\end{array}$ \\
\hline Terms-of-trade shocks & $\begin{array}{l}\text { Log differences of the terms-of- } \\
\text { trade index. }\end{array}$ & World Bank (2002). \\
\hline Period shifts & Period dummy variables. & Authors' construction. \\
\hline
\end{tabular}

TABLE B2

DESCRIPTIVE STATISTICS: BASIC STATISTICS ${ }^{a}$

\begin{tabular}{lrcrr}
\hline Variable & Average & Standard deviation & Minimum & Maximum \\
\hline Growth rate of GDP per capita & 1.26 & 2.58 & -7.94 & 8.39 \\
Initial GDP per capita & 8.52 & 1.03 & 6.43 & 10.24 \\
Investment in human capital & 3.78 & 0.78 & 0.65 & 4.92 \\
Domestic credit (\% GDP) & 3.68 & 0.62 & 1.26 & 5.24 \\
Institutions & 0.49 & 1.83 & -3.26 & 3.47 \\
Government consumption & 2.67 & 0.39 & 1.46 & 3.64 \\
Inflation rate (\%) & 4.74 & 0.18 & 4.59 & 6.14 \\
Real exchange rate overvaluation & 107.44 & 44.00 & 47.19 & 555.03 \\
Terms-of-trade shocks & -0.20 & 4.08 & -15.05 & 18.65 \\
Trade openness & 0.07 & 0.45 & -1.17 & 1.39 \\
Financial openness & 0.20 & 0.24 & 0.00 & 2.54 \\
\hline
\end{tabular}

Source: Authors' calculations.

a. Based on a sample of seventy-eight countries, generating 371 observations (in non-overlapping five-year-period averages). 


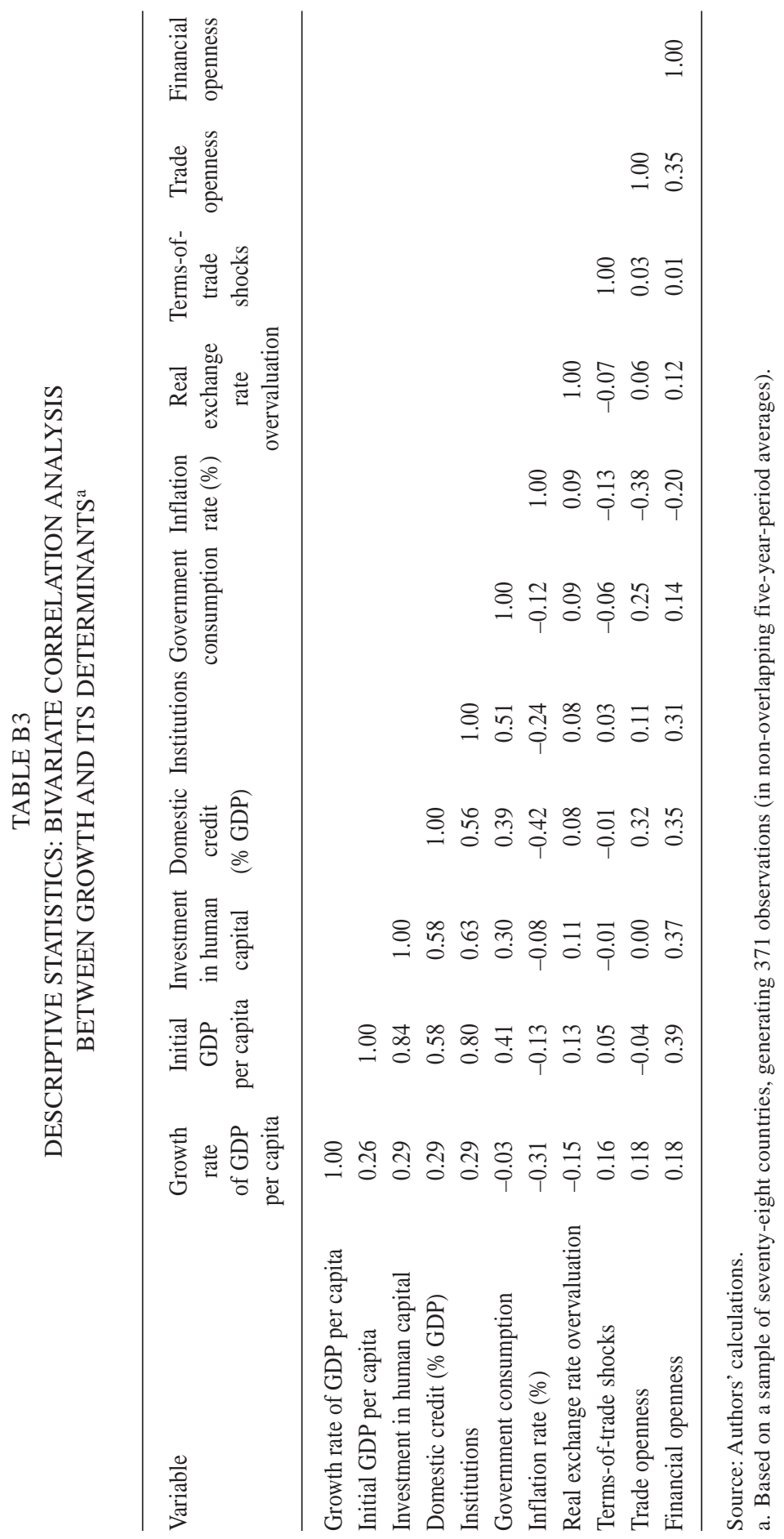




\section{TABLE B4 \\ FORECASTING MODELS USED TO COMPUTE THE CONTINUOUS TREND SCENARIO}

Variable Procedure

I. Structural policies Human capital

Financial development

Institutions

Government consumption

II. Stabilization policies Inflation rate

Real exchange rate overvaluation

\section{III.Openness}

Trade openness

Financial openness

IV. External conditions Terms-of-trade shocks

\footnotetext{
V. Convergence Initial GDP per capita
}

Projected for 2001-2010 using OLS regression models incorporating linear or quadratic trends and a convergence effect. Inclusion criterion: (i) increase fit of equation and (ii) generate plausible values for the projected variable.

Projected for 2001-2010 using OLS regression models incorporating linear or quadratic trends and using ARMA terms. Inclusion criterion: (i) increase fit of equation and (ii) generate plausible values for the projected variable.

Projected for 2001-2010 using OLS regression models incorporating linear or quadratic trends and a convergence effect. Inclusion criterion: (i) increase fit of equation and (ii) generate plausible values for the projected variable.

Projected for 2001-2010 using OLS regression models incorporating linear or quadratic trends and using ARMA terms. Inclusion criterion: (i) increase fit of equation and (ii) generate plausible values for the projected variable.

Projected for 2006-2010 using the inflation target established by the Central Bank. Consensus Forecast predictions were used for 2004-2005, while observed inflation was used for 2001-2003. Projected for 2001-2010 using OLS regression models incorporating linear or quadratic trends and using ARMA terms. Inclusion criterion: (i) increase fit of equation and (ii) generate plausible values for the projected variable.

Projected for 2001-2010 using OLS regression models incorporating linear or quadratic trends, ARMA terms and a convergence effects. Inclusion criterion: (i) increase fit of equation and (ii) generate plausible values for the projected variable.

Projected for 2001-2010 using OLS regression models incorporating linear or quadratic trends, ARMA terms and a convergence effects. Inclusion criterion: (i) increase fit of equation and (ii) generate plausible values for the projected variable.

Projected for 2004-2010 using OLS regression models incorporating linear or quadratic trends and using ARMA terms. Actual series used for 2001-2003.

GDP per capita in 2005 projected with the expected growth rate for the period 2001-2005, actual values of GDP in 20012005, and estimated panel data models.

Source: Loayza, Fajnzylber, and Calderón (2005). 


\section{REFERENCES}

Acemoglu, D., and F. Zilibotti (2001). "Productivity Differences." Quarterly Journal of Economics 116(2): 563-606.

Alfaro, L., A. Chanda, S. Kalemli-Ozcan, and S. Sayek (2004). "FDI and Economic Growth: The Role of Local Financial Markets." Journal of International Economics 64(1): 89-112.

Alonso-Borrego, C., and M. Arellano (1999). "Symmetrically Normalized InstrumentalVariable Estimation Using Panel Data." Journal of Business and Economic Statistics 17(1): 36-49.

Arellano, M., and S. Bond (1991). "Some Tests of Specification for Panel Data: Monte Carlo Evidence and an Application to Employment Equations." Review of Economic Studies 58(2): 277-297.

Arellano, M., and O. Bover (1995). "Another Look at the Instrumental-Variable Estimation of Error-Components Models." Journal of Econometrics 68(1): 29-52.

Aziz, J., and R.F. Wescott (1997). "Policy Complementarities and the Washington Consensus." IMF Working Paper WP/97/118, September.

Barro, R. J. (1991). "Economic Growth in a Cross Section of Countries." Quarterly Journal of Economics 106 (May, Papers and Proceedings, 1990): 407-443.

Barro, R. J., and J.-W. Lee (2001). "International Data on Educational Attainment: Updates and Implications." Oxford Economic Papers 53(3): 541-563.

Barro, R. J., and X. Sala-i-Martin (1995). Economic Growth. New York: McGraw-Hill.

Beck, T., A. Demirgüç-Kunt, and R. Levine (2000). "A New Database on Financial Development and Structure." World Bank Economic Review 14(3): 597-605.

Bekaert, G., C. R. Harvey, and C. Lundblad (2001). "Emerging Equity Markets and Economic Development." Journal of Development Economics 66(2): 465-504.

(2005). "Did Financial Liberalization Spur Growth?” Journal of Financial Economics, forthcoming.

Blundell, R., and S. R. Bond (1998). "Initial Conditions and Moment Restrictions in Dynamic Panel Data Models." Journal of Econometrics 87(1): 115-143.

Bolaky, B., Freund, C. (2004). “Trade, Regulations, and Growth.” The World Bank Policy Research Working Paper No. 3255, April.

Borensztein, E., J. De Gregorio, and J.-W. Lee (1998). "How Does Foreign Direct Investment Affect Economic Growth?" Journal of International Economics 45(1): 115-135.

Boyd, J. H., and B. D. Smith (1992). "Intermediation and the Equilibrium Allocation of Investment Capital: Implications for Economic Development." Journal of Monetary Economics 30(3): 409-432.

Burnside, C., and D. Dollar (2000). "Aid, Policies, and Growth." American Economic Review 90(4): 847-868.

Bravo-Ortega, C., and J. De Gregorio (2005). "The Relative Richness of the Poor? Natural Resources, Human Capital, and Economic Growth." Policy research working paper WPS3484, February. Washington: World Bank.

Calderón, C., and J. R. Fuentes (2006). "Why some reformers grow faster, while others don't? Mimeo, Central Bank of Chile.

Calderón, C., N. Loayza, and K. Schmidt-Hebbel (2004). "External Conditions and Growth." Working paper 292. Santiago: Central Bank of Chile.

Coe, D., and E. Helpman (1995). "International R\&D Spillovers." European Economic Review 39: 859-587. 
De Gregorio, J. (1999). "Financial Integration, Financial Development and Economic Growth." Estudios de Economía 26(2): 137-161.

Dollar, D. (1992). "Outward-Oriented Developing Economies Really Do Grow More Rapidly: Evidence from 95 LDCs, 1976-1985.” Economic Development and Cultural Change 40(3): 523-544.

Easterly, W. (2001). "The Middle Class Consensus and Economic Development.” Journal of Economic Growth 6(4): 317-335.

Easterly, W. (2005). "National Policies and Economic Growth: A Reappraisal." Forthcoming in: Aghion, P. and S. Durlauf (eds.), Handbook of Economic Growth. Amsterdam: North-Holland, Elsevier Science.

Easterly, W., N. Loayza, and P. Montiel (1997). "Has Latin America's Post-Reform Growth Been Disappointing?" Journal of International Economics 43(3-4): 287-311.

Edison, H. J., R. Levine, L. Ricci, and T. Slok (2002). "International Financial Integration and Economic Growth." Journal of International Money and Finance 21: 749-776.

Edwards, S. (1998). "Openness, Productivity, and Growth: What Do We Really Know?" Economic Journal 108(447): 383-398.

Eichengreen, B. (2001). "Capital Account Liberalization: What Do Cross-Country Studies Tell Us?" The World Bank Economic Review 15(3): 341-365.

Engen, E. M., and J. S. Skinner (1996). "Taxation and Economic Growth.” Working paper 5826. Cambridge, Mass.: National Bureau of Economic Research.

Fischer, S. (1993). “The Role of Macroeconomic Factors in Growth.” Journal of Monetary Economics 32(3): 485-511.

Gallego, F., and N. Loayza (2002). "The Golden Period for Growth in Chile: Explanations and Forecasts." In Economic Growth: Sources, Trends, and Cycles, edited by Norman Loayza and Raimundo Soto. Santiago, Chile: Central Bank of Chile.

Griliches, Z., and J. A. Hausman (1986). "Errors in Variables in Panel Data." Journal of Econometrics 31(1): 93-118.

Kaufmann, D., A. Kraay, and P. Zoido-Lobatón (1999). "Governance Matters." Policy research working paper 2196. Washington: World Bank.

Keller, W. (2004). "International Technology Diffusion." Journal of Economic Literature 42(3): 752-782.

Klein, M.W (2003). "Capital Account Openness and the Varieties of Growth Experience", NBER Working Paper 9500, February.

Klein, M. W., and G. Olivei (1999). "Capital Account Liberalization, Financial Depth, and Economic Growth." Working paper 7384. Cambridge, Mass.: National Bureau of Economic Research.

Knack, S., and P. Keefer (1995). "Institutions and Economic Performance: Cross-Country Tests Using Alternative Institutional Measures." Economics and Politics 7(3): 207-227.

Lane, P. R., and G.-M. Milesi-Ferretti (2001). "The External Wealth of Nations: Measures of Foreign Assets and Liabilities for Industrial and Developing Countries." Journal of International Economics 55(2): 263-294.

(2003). "International Financial Integration.” IMF Staff Papers 50 (special issue): 82-113.

Levin, V. and L. K. Raut (1997). "Complementarities between Exports and Human Capital in Economic Growth: Evidence from the Semi-industrialized Countries." Economic Development and Cultural Change 46(1): 155-175. 
Levine, R. (1997). "Financial Development and Economic Growth: Views and Agenda." Journal of Economic Literature 35(2): 688-726.

Levine, R. (2001). "International Financial Integration and Economic Growth." Review of International Economics 9(4): 684-698.

Levine, Ross, Norman Loayza, and Thorsten Beck (2000). "Financial Intermediation and Growth: Causality and Causes." Journal of Monetary Economics 46(1): 31-77.

Loayza, N., P. Fajnzylber, and C. Calderón (2005). "Economic Growth in Latin America and the Caribbean: Stylized Facts, Explanations and Forecasts." World Bank Latin American and the Caribbean Studies, April 2005.

Lucas, R. E., Jr. (1988). "On the Mechanics of Economic Development." Journal of Monetary Economics 22(1): 3-42.

Mauro, P. (1995). "Corruption and Growth.” Quarterly Journal of Economics 110(3): 681-712.

Ok, W. (2004). "Policy Complementarities in Economic Development: The Case of South Korea." The Journal of the Korean Economy 5(2): 7-41.

Quinn, D. P. (1997). "The Correlates of Change in International Financial Regulation." American Political Science Review 91(3): 531-551.

Rodrik, D. (2005). "Growth Strategies," in P. Aghion and S. Durlauf, eds., Handbook of Economic Growth, North-Holland.

Rodríguez, F., and D. Rodrik (2000). "Trade Policy and Economic Growth: A Skeptics Guide to the Cross-National Evidence." In: Bernanke, B. and K. Rogoff (eds.), NBER Macroeconomics Annual 15. Cambridge, MA: MIT Press.

Sachs, J. D., and A. Warner (1995). "Economic Reform and the Process of Global Integration." Brookings Papers on Economic Activity 1(1995): 1-95.

Summers, R., and A. Heston (1991). "The Penn World Table (Mark 5): An Expanded Set of International Comparisons, 1950-1998." Quarterly Journal of Economics 106(2): 327-368.

Temple, J. (1999). “The New Growth Evidence.” Journal of Economic Literature 38 (March): 112-156.

Wacziarg, R., and K. H. Welch (2003). "Trade Liberalization and Growth: New Evidence." Working paper 10152. Cambridge, Mass.: National Bureau of Economic Research.

World Bank (2003). World Development Indicators, CD-ROM. Washington, D.C.: The World Bank. 